\title{
KESIAPAN SPAM REGIONAL KARTAMANTUL DI KABUPATEN SLEMAN: STUDI PADA 4 (EMPAT) SPAMDES
}

\author{
Endiarjati Dewandaru Sadono, Amirullah Setya Hardi, dan Bintang Prasodjo \\ Fakultas Ekonomika dan Bisnis Universitas Gadjah Mada \\ Email:endiarjati.dewandaru@gmail.com
}

\begin{abstract}
SPAM Regional Kartamantul is one of the steps of Special Region of Yogyakarta Government to realize the RPJMN 2015-2019 in the provision of drinking water for 100 percent of the population in 2019. Because Sleman District is one of the areas included in SPAM Regional Kartamantul, this study seeks to identify the readiness of 4 SPAMDes in this district to welcome SPAM Regional Kartamantul. The results of this study are expected to be descriptive assessment of the readiness of those Regional SPAM. This study identified that some SPAMDes are still not ready to be integrated with SPAM Regional Kartamantul. In the future, the ready SPAMDes should be directed to cooperate with or be formed into BUMDes. In adittion, clear tariff arrangements are required for entrepreneurs of fishing ponds, laundry or car washers, whether they are subject to progressive rates or are not allowed to become SPAMDes customers. Nevertheless, there are still a subjective element of the Chairman of PERPAMDES Association that determines the successful and unsuccessful SPAMDes. Therefore, we suggest that in the next study the standard indicators needs to be identified so that the subjective element can be reduced.
\end{abstract}

Keywords: BUMdes; Chairman of PERPAMDES Association; Sleman; SPAM Regional Kartamantul; SPAMDes.

\begin{abstract}
ABSTRAK
SPAM Regional Kartamantul adalah salah satu langkah Pemerintah Daerah Istimewa Yogyakarta untuk mewujudkan amanat RPJMN 2015-2019 dalam penyediaan air minum bagi 100 persen penduduk pada tahun 2019. Karena Kabupaten Sleman adalah salah satu daerah yang masuk dalam SPAM Regional Kartamantul, maka studi ini berupaya mengidentifikasi kesiapan pada 4SPAMDes di Kabupaten Sleman untuk menyongsong SPAM Regional Kartamantul. Hasil dari studi ini diharapkan menjadi penilaian deskriptif dari kesiapan SPAM Regional tersebut. Studi ini berhasil mengidentifikasi bahwa beberapa SPAMDes masih belum siap untuk diintegrasikan dengan SPAM Regional Kartamantul. Ke depan, SPAMDes yang sudah siap sebaiknya diarahkan untuk bekerjasama dengan atau dibentuk menjadi BUMDes. Selain itu, dibutuhkan pengaturan tarif yang jelas bagi pengusaha kolam pemancingan, laundry dan cuci mobil, apakah dikenakan tarif yang progresif atau tidak dibolehkan sekalian menjadi pelanggan SPAMDes. Namun demikian, studi ini masih ada unsur subjektif dari Ketua Paguyuban PERPAMDES yang menentukan SPAMDes sukses dan kurang sukses. Oleh karenanya, peneliti menyarankan agar pada studi berikutnya terkait penilaian kesiapan SPAM Regional Kartamantul perlu diidentifikasi indikator baku agar unsur subjektif bisa dikurangi.
\end{abstract}

Kata Kunci: BUMdes; Chairman of PERPAMDES Association; Sleman; SPAM Regional Kartamantul; SPAMDes. 


\section{PENGANTAR}

Upaya penyediaan air minum di Indonesia sudah dilakukan sejak zaman Pelita I dan Pelita II. Bahkan, pembangunan saluransaluran air sudah dilakukan sejak zaman penjajahan Belanda dan Jepang. Selama dua periode Pelita, permasalahan utamanya meliputi: (1) kurangnya teknisi yang terampil di bidang penyediaan air minum; (2) rendahnya kemampuan industri dalam negeri untuk memproduksi peralatan dan perlengkapan; (3) ketergantungan yang tinggi pada konsultan asing; (4) kurangnya sumber pendanaan dan valuta asing untuk membeli peralatan dan perlengkapan yang dibutuhkan dari luar negeri; dan (5) biaya yang dikeluarkan Pemerintah untuk membangun sistem penyediaan air minum terus meningkat, tetapi pendapatan yang diterima setelahnya masih sedikit (Notosugondo, 1975). Permasalahanpermasalahan tersebut berusaha diatasi Pemerintah pada periode pembangunan selanjutnya dengan memperjelas regulasi yang berkaitan dengan penyediaan air minum.

Pada tahun 1994, sekitar 40 persen penduduk perkotaan Indonesia (27 juta orang) memiliki akses terhadap air minum perpipaan, sedangkan di daerah pedesaan, hanya sekitar 10 persen (10 juta orang) saja yang memiliki akses (Rietvield et al., 2000). Hingga tahun 2016, persentase penduduk yang memiliki akses terhadap air minum terus meningkat. Selain berkaitan dengan akses, air minum juga berkaitan dengan sanitasi dan penyediaannya harus dilakukan secara terintegrasi antara pusat dan daerah. Pada peraturan presiden (Perpres) No. 185 Tahun 2014, dijelaskan bahwa Pemerintah, Pemerintah Provinsi dan Pemerintah Kabupaten/Kota bertanggung jawab atas pembinaan percepatan penyediaan air minum dan sanitasi sesuai asas desentralisasi, dekonsentrasi, dan tugas pembantuan.

Di era pemerintahan Presiden Joko Widodo, penyediaan air minum menjadi salah satu prioritas pembangunan dan sudah ditetapkan dalam Rencana Pembangunan Jangka Menengah Nasional (RPJMN) Tahun 2015-2019. Dalam dokumen tersebut dijelaskan bahwa pada tahun 2019 ditargetkan 100 persen air minum yang layak bagi 100 persen penduduk Indonesia. Untuk mewujudkan amanat tersebut Pemerintah Daerah Istimewa Yogyakarta (DIY) telah merencanakan untuk membentuk Sistem Penyediaan Air Minum Regional Yogyakarta - Sleman - Bantul (SPAM Regional Kartamantul) pada tahun 2019. SPAM Regional Kartamantul adalah salah satu upaya yang dilakukan oleh Pemerintah DIY untuk menyediakan air minum bagi 100 persen penduduk di tiga kabupaten/kota tersebut. Karena Kabupaten Sleman adalah salah satu daerah yang akan dilewati SPAM Regional Kartamantul, maka Pemerintah Kabupaten Sleman berupaya menyusun strategi kebijakan untuk mencapai target RPJMN 2015-2019 dan rencana Pemerintah DIY tersebut.

Studi ini bertujuan untuk mengidentifikasi kesiapan pembentukan SPAM Regional Kartamantul di Kabupaten Sleman karena SPAM di Kabupaten Sleman begitu kompleks, maka studi ini hanya fokus pada empat Sistem Penyediaan Air Minum Pedesaan (SPAMDes). Keempat SPAMDes yang menjadi objek penelitian dipilih berdasarkan cara pengambilan airnya, yaitu yang menggunakan sistem pompa dan sistem gravitasi. Masing-masing kategori dipilih SPAMDes yang berhasil dan kurang berhasil. Penentuan kriteria SPAMDes yang sukses dan kurang sukses dilakukan melalui musyawarah dengan Ketua Paguyuban Persatuan Penyedia Air Minum Pedesaan (PERPAMDES) Kabupaten Sleman. Sementara itu, data terkait kondisi SPAM di Kabupaten Sleman dan arah pengembangannya diperoleh dari hasil Focus Group Discussion (FGD) dengan Pemerintah Kabupaten Sleman. Hasil dari studi ini diharapkan menjadi penilaian deskriptif dari kesiapan SPAM Regional tersebut.

\section{Sistem Penyediaan Air Minum}

Meskipun untuk meningkatkan ketersediaan air minum dibutuhkan identifikasi sumber baru, namun pendekatan berbasis penawaran (supply-oriented approach) murni kemungkinan akan menghasilkan dampak yang kontraproduktif. Rumah menggunakan sumur pompa dan bisnis biasanya menggunakan air lebih banyak daripada yang 
sebenarnya dibutuhkan. Dengan hanya fokus pada sisi penawaran saja, maka akan mengurangi ketersediaan air untuk penggunaan lain. Di samping itu, semakin tingginya angka pertumbuhan penduduk mengharuskan semakin banyak air minum yang harus disediakan. Akan tetapi, bukan berarti volume penyediaan harus ditingkatkan sedemikian rupa ketika permintaannya naik. Permintaan bersifat relatif. Jumlah air yang dibutuhkan tergantung pada efisiensi sistem penyaluran dan pengguna akhir (Matzger dan Moench, 1994).

Menurut Peraturan Pemerintah No. 122 Tahun 2015, Sistem Penyediaan Air Minum adalah satu kesatuan sarana dan prasarana penyediaan air minum. SPAM diselenggarkan dengan tujuan: (a) Tersedianya pelayanan air minum untuk memenuhi hak rakyat atas air minum; (b) Terwujudnya pengelolaan dan pelayanan air minum yang berkualitas dengan harga terjangkau; (c) Tercapainya kepentingan yang seimbang antara pelanggan dan BUMN, BUMD, UPT, UPTD, Kelompok Masyarakat, dan Badan Usaha. (d) Tercapainya penyelenggaraan air minum yang efektif dan efisien untuk memperluas cakupan pelayanan air minum.

Secara kelembagaan, terdapat empat lembaga penyelenggara SPAM, yaitu BUMN/ BUMD, UPT/UPTD, Kelompok Masyarakat, dan Badan Usaha. Khusus untuk yang dimakud kelompok masyarakat dalam aturan ini adalah kumpulan, himpunan atau paguyuban yang dibentuk masyarakat dalam penyelenggaraan SPAM untuk memenuhi kebutuhan diri sendiri. Dalam hal ini, Sistem Penyediaan Air Minum (SPAM) terdiri dari dua jenis, yaitu SPAM jaringan perpipaan dan SPAM bukan jaringan perpipaan. Di dalam Kebijakan Strategis Air Minum Kabupaten Sleman (2015), dijelaskan bahwa penyediaan air bersih di Kabupaten Sleman untuk masyarakat di perkotaan dilayani oleh Perusahaan Daerah Air Minum (PDAM) sedangkan di pedesaan dilayani oleh Sistem Penyediaan Air Minum Pedesaan (SPAMDes).

\section{Penyediaan Air Minum di Pedesaan}

Upaya penyediaan air bersih/minum di pedesaan harus melibatkan seluruh pemangku kepentingan terkait. Belajar dari Swajaldhara Guidlelines, penerapan pedoman yang diinisiasi oleh lembaga eksternal (World Bank) tanpa pelibatan Pemerintah dan masyarakat hanya akan berakhir dengan banyak kekurangan atau tidak optimal (Cullet, 2009). Hampir sama dengan pengalaman India, kurangnya kesadaran politik dan koordinasi antarpemangku kepentingan membuat permasalahan penyediaan air bersih di Cebu City, Filipina tidak dapat diatasi. Peran Pemerintah dan masyarakat dalam perencanaan, formulasi kebijakan serta monitoring dan evaluasi haruslah diaktifkan. Peran swasta dan lembaga eksternal tetap dibutuhkan, terutama ketika anggaran Pemerintah tidak dapat menutup seluruh biaya penyediaan air bersih.

Masalah kelembagaan dalam penyediaan air minum di pedesaan sangat penting untuk diperhatikan (Heikoop, 2001; Pant, 1996). Jika dikelola oleh Pemerintah dan tarif yang dikenakan sangat rendah atau bahkan gratis, apakah mampu beroperasi secara berkelanjutan mengingat air minum menyangkut hajat hidup orang banyak seperti yang diamanatkan dalam Pasal 33 UUD 1945. Lalu, jika dikelola oleh swasta, maka jangan sampai ada selisih tarif yang cukup besar antara pelanggan dan nonpelanggan (diskriminasi). Selain itu, formulasi perhitungan tarif, seperti pendapatan rumah tangga, jarak rumah pelanggan dan sumber air dan seterusnya, harus diperhatikan agar tidak terjadi disparitas tarif yang cukup besar antara pelanggan yang satu dengan yang lainnya. Pungutan liar oleh oknum tertentu juga harus diminimalisir.

\section{Penetapan Harga Air Minum}

Ada semacam kesepakatan umum di kalangan usaha penyedia air minum bahwa air minum yang disediakan sudah semestinya dikenakan biaya sesuai dengan volume yang digunakan oleh konsumen. Hal ini cukup logis karena butuh biaya untuk memproduksi, memurnikan dan mendistribusikan air minum kepada konsumen. Selain itu, peralatan dan perlengkapan untuk menyediakan air minum sangat mahal. Setelah peralatan dan 
perlengkapan tersebut terpasang, maka perlu biaya untuk operasional dan perawatan sistem tersebut. Oleh karena itu, sangatlah adil apabila biaya untuk semua hal tersebut ditutup dengah hasil penjualan air minum yang diproduksi. Hal ini membutuhkan penetapan harga untuk air minum tersebut (Saha, 1971).

Penentuan harga air minum membutuhkan perhitungan yang matang. Apabila harga yang ditetapkan terlalu tinggi, maka kebijakan tersebut akan merugikan orang yang tidak mampu atau miskin. Sementara itu, apabila harga air minum gratis, maka akan menguntungkan orang yang mampu membeli air minum dan mengakibatkan pemborosan. Selain itu, belajar dari kasus di AsansulDurgapur, India maka perlu juga diatur mekanisme bagi mereka yang memiliki sumur pompa pribadi.

Penelitian ini menggunakan metode deskriptif analitis dengan pendekatan studi kasus untuk mengidentifikasi kesiapan 4 SPAMDes di Kabupaten Sleman dalam menyongsong SPAM Regional Kartamantul pada tahun 2019. Adapun data-data yang digunakan dalam penelitian ini ada yang bersumber dari FGD dengan Pemerintah Kabupaten Sleman dan ada yang bersumber dari observasi lapangan. Observasi lapangan dilakukan peneliti pada bulan November 2017. Peneliti juga berhasil melakukan wawancara dengan Ketua Paguyuban PERPAMDES untuk mendapatkan informasi yang mendalam mengenai kondisi SPAMDes yang diobservasi dalam penelitian ini.

\section{PEMBAHASAN \\ Gambaran Umum SPAMDes di Kabupaten Sleman}

Di Kabupaten Sleman, terdapat 353 SPAMDes yang beroperasi menurut SK Bupati. Paguyuban-paguyuban tersebut tersebar di 52 desa pada 14 kecamatan. Gambar 1 berikut menunjukkan sebaran SPAMDes di Kabupaten Sleman pada tahun 2016. Mayoritas SPAMDes berada di Kecamatan Turi, Pakem, dan Tempel. Jumlah SPAMDes di tiga kecamatan tersebut mencapai 228 unit atau 67 persen dari total SPAMDes yang ada di Kabupaten Sleman.
Perlu dicatat bahwa di Kecamatan Depok dan Kalasan tidak terdapat SPAMDes dan sampai dengan tahun 2016 bahwa jumlah pengguna diperkirakan mencapai 27.048 kepala keluarga atau kurang lebih 88.326 jiwa.

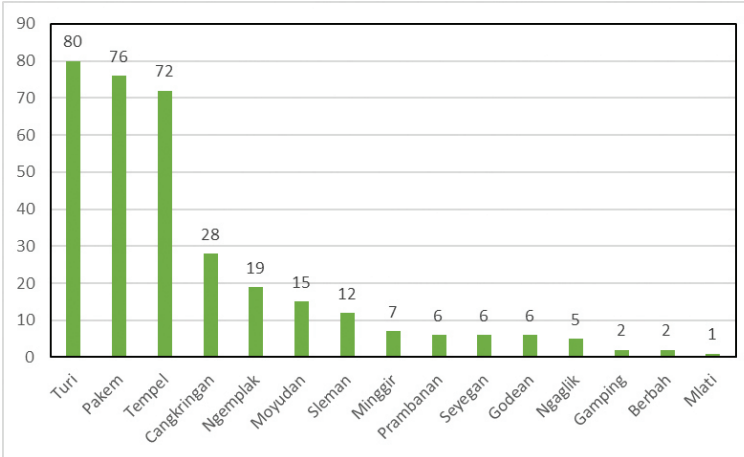

Gambar 1. Sebaran SPAMDes di Kabupaten Sleman Menurut Kecamatan, 2016

Sumber: Lokakarya Sosialisasi Penyusunan RAD AMPL Kabupaten Sleman (2017)

Air yang dialirkan oleh SPAMDes di Kabupaten Sleman ada yang bersumber dari air permukaan dan ada yang dari air dalam. Pada umumnya SPAMDes yang mengalirkan air permukaan berlokasi di daerah Sleman bagian utara atau di sekitar lereng Gunung Merapi yang dialiri mata air. Sementara itu, SPAMDes yang mengalirkan air dalam cenderung berlokasi di daerah Sleman agak tengah atau selatan. SPAMDes yang memanfaatkan air permukaan biasanya menggunakan sistem gravitasi, sedangkan yang memanfaatkan air dalam biasanya menggunakan sistem pompa.

\section{SPAMDes Sistem Gravitasi}

SPAMDes dengan Sistem Gravitasi yang menjadi observasi adalah SPAMDes Tirto Makmur dan SPAMDes di Dusun Dukuh. SPAMDes Tirto Makmur dianggap sudah sukses, sedangkan SPAMDes di Dusun Dukuh dianggap kurang sukses. Berikut akan dijelaskan secara lebih rinci.

\section{SPAMDes Tirto Makmur}

SPAMDes Tirto Makmur berlokasi di Dusun Kadirojo, Desa Margorejo, Kecamatan Tempel. Paguyuban ini sudah ada sejak tahun 
2012, tetapi baru efektif sejak tahun 2015. Air yang dikelola SPAMDes ini bersumber dari sumur yang terletak di tanah kas desa. Pasokan air selama ini cukup lancar dan tidak berfluktuasi. Kualitas air yang dialirkan juga cukup baik serta sudah dilakukan uji laboratorium di Dinas Kesehatan Kabupaten Sleman pada tahun 2015 dan dinyatakan layak. Sejauh ini, SPAMDes Tirto Makmur baru melakukan kerjasama intensif dengan Ketua Paguyuban PERPAMDES saja, belum ada kerjasama dengan BUMDes setempat.

Perangkat produksi yang sudah ada di SPAMDes Tirto Makmur antara lain: (1) bangunan pengolahan; (2) perangkat operasional; (3) alat pengukur dan pemantauan; serta (2) bangunan penampungan hasil produksi. Proses produksi air di SPAMDes ini dapat dilihat pada Gambar 2 berikut. Mula-mula air diambil dari sumur utama, lalu ditampung di bak penampungan utama. Selanjutnya air dialirkan dengan pipa dari bak penampungan utama ke empat bak penampungan kecil. Kemudian, dari bak penampungan kecil tersebut air dialirkan ke rumah-rumah pelanggan dengan menggunakan pipa yang lebih kecil. Sejauh ini, peralatan yang ada belum pernah diganti sejak dibangun karena kondisinya masih bagus. Bentuk inovasi dan pemanfaatan teknologi baru di SPAMDes ini adalah penggunaan kaporit. Di masa mendatang, akan dilakukan perluasan jaringan distribusi karena ada dua sumur utama, tetapi baru satu sumur yang dimanfaatkan. Kendalanya adalah kurangnya modal untuk menyediakan pompa dan pipa baru.

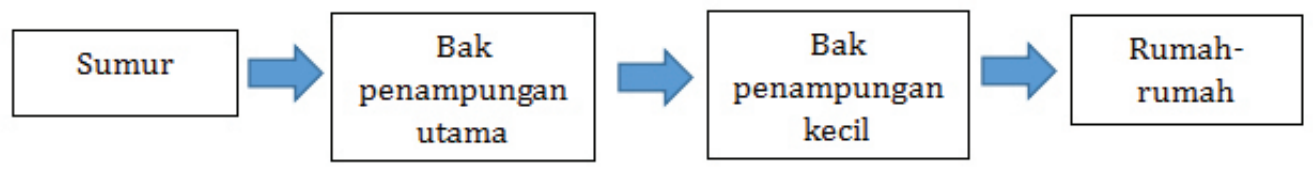

Gambar 2. Proses Produksi Air di SPAMDes Tirto Makmur

Jumlah pelanggan SPAMDes Tirto Makmur sejauh ini berjumlah 67 kepala keluarga, sementara jumlah kepala keluarga di Dusun Kadirojo ada 140, sehingga SPAMDes ini mampu melayani sekitar 47,86 persen kepala keluarga di Dusun Kadirojo. Jumlah pelanggan tersebut tidak mengalami perubahan sejak SPAMDes ini pertama kali didirikan. Mayoritas pelanggan bekerja sebagai petani, pegawai, dan buruh.

Pengurus SPAMDes Tirto Makmur terpisah dari perangkat RW atau dusun. SPAMDes ini sudah memiliki AD/ART. Setiap dua bulan sekali, pengurus harian mengadakan pertemuan (di luar insidentil). Untuk seluruh anggota, pertemuan dilakukan setiap enam bulan sekali. Pertemuan dengan seluruh anggota ini salah satunya membahas evaluasi dan penetapan harga. Sejak awal berdiri sampai sekarang harga yang ditetapkan masih sama, yaitu setiap pelanggan dikenakan abonemen sebesar Rp3.000,00 perbulan. Selanjutnya, per $\mathrm{m}^{3}$ dikenakan biaya sebesar Rp500,00. Besarnya pemakaian pelanggan dapat diukur dengan water meter, sehingga pemakaiannya dapat senantiasa dipantau. Setiap bulan ada petugas yang memantau dan biasanya perbulan setiap kepala keluarga menghabiskan 20 sampai $40 \mathrm{~m}^{3}$. Masyarakat memanfaatkan air yang dikelola SPAMDes Tirto Makmur untuk kebutuhan Mandi, Cuci, dan Kakus (MCK) saja.

\section{SPAMDes di Dusun Dukuh}

SPAMDes di Dusun Dukuh, Desa Donokerto, Kecamatan Turi ini belum memiliki nama resmi karena baru sebatas kelompok gotong-royong. Akan tetapi, paguyuban ini sudah ada sejak tahun 2007. Air yang dikelola SPAMDes ini bersumber dari sumur dari dusun lain, seperti Dusun Gabugan dan Dusun Randusongo. Sumur-sumur tersebut ada yang terletak di tanah kas desa dan ada yang terletak di tanah penduduk. Menariknya, penduduk yang tanahnya digunakan untuk sumur tidak mendapatkan kompensasi, hanya berdasarkan kesepakatan kerelaan saja. Pasokan air selama ini kurang lancar karena deras saat musim penghujan dan kecil saat musim kemarau. 
Perangkat produksi yang sudah ada di SPAMDes Dusun Dukuh antara lain: (1) bangunan pengolahan; (2) perangkat operasional; dan (3) bangunan penampungan hasil produksi. Proses produksi air di SPAMDes ini dapat dilihat pada Gambar 3 berikut. Mula-mula air diambil dari sumur utama, lalu ditampung di bak penampungan. Selanjutnya air dialirkan dengan pipa dari bak penampungan rumah-rumah pelanggan.
Sejauh ini, peralatan yang sudah ada pernah diganti ketika rusak. Akan tetapi, penggantian peralatan tersebut sangat bergantung dari bantuan Pemerintah Kabupaten Sleman, Pemerintah Daerah Istimewa Yogyakarta, dan Balai Besar Sungai Serayu-Opak. Belum ada bentuk inovasi dan pemanfaatan teknologi baru yang digunakan oleh SPAMDes ini, tetapi di masa mendatang ada rencana untuk pengembangan air minum.

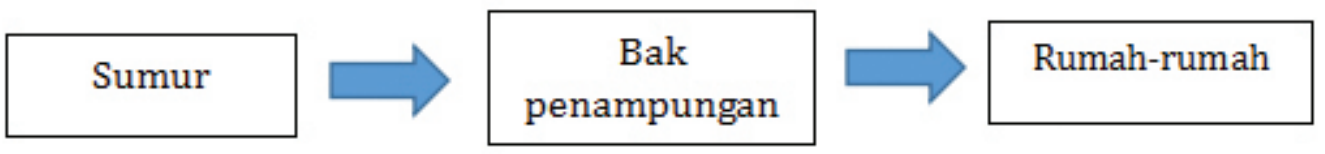

Gambar 3. Proses Produksi Air di SPAMDes Dusun Dukuh

Jumlah pelanggan SPAMDes di Dusun Dukuh sejauh ini berjumlah 36 kepala keluarga, sementara jumlah kepala keluarga di Dusun Dukuh ada 130, sehingga Perpamdes ini mampu melayani sekitar 27,69 persen kepala keluarga di Dusun Dukuh. Mayoritas pelanggan bekerja sebagai petani, terutama petani salak pondoh. Sejak awal berdiri hingga sekarang, jumlah pelanggan berkurang 20 persen setiap tahunnya karena menurunnya debit air sehingga lebih memilih menggunakan sumur pribadi.

Pengurus SPAMDes di Dusun Dukuh terintegrasi dengan RT/Dusun dan belum banyak melibatkan peran Karang Taruna, hanya sebatas melakukan kerjasama intensif dengan Ketua Paguyuban PERPAMDES saja. Setiap enam bulan sekali, pengurus SPAMDes ini melalukan musyawarah untuk membahas evaluasi dan penetapan harga. Pada tahun 2007, harga ditetapkan sebesar Rp3.000/ bulan/kepala keluarga, lalu pada tahun 2012 dinaikkan menjadi Rp5.000/bulan/ kepala keluarga. Dasar penetapan harga ini cenderung melihat contoh di dusun lain. Menariknya, berapapun penggunaan air tetap Rp5.000/bulan/kepala kaluarga. Akan tetapi, berdasarkan kesepakatan, air hanya boleh digunakan untuk kebutuhan rumah tangga, bukan untuk pertanian, perkebunan, kolam, dan lain-lain.

\section{SPAMDes Sistem Pompa}

SPAMDes dengan Sistem Pompa yang menjadi observasi adalah SPAMDes Penggung Air Bersih Tirta Manunggal dan SPAMDes Banyu Sejati. SPAMDes Penggung Air Bersih Tirta Manunggal dianggap sudah sukses, sedangkan SPAMDes Banyu Sejati dianggap kurang sukses. Berikut akan dijelaskan secara lebih rinci.

\section{SPAMDes Penggung Air Bersih Tirta Manunggal}

SPAMDes Penggung Air Bersih Tirta Manunggal berlokasi di Dusun Jitar-Pingitan, Desa Sumberarum, Kecamatan Moyudan dan sudah berdiri sejak tahun 2011. Air yang dikelola SPAMDes ini bersumber dari sumur yang terletak di tanah negara (Kementerian Pekerjaan Umum), tepatnya di tepi sungai Progo. Pasokan air selama ini cukup lancar dan tidak berfluktuasi. Kualitas air yang dialirkan juga cukup baik serta sudah dilakukan uji laboratorium sebanyak dua kali di Dinas Kesehatan Kabupaten Sleman pada tahun 2012 dan dinyatakan layak. Sejauh ini, SPAMDes Penggung Air Bersih Tirta Manunggal baru melakukan kerjasama intensif dengan Ketua Paguyuban PERPAMDES saja, belum ada kerjasama dengan BUMDes setempat.

Jumlah pelanggan SPAMDes Penggung Air Bersih Tirta Manunggal sejauh ini berjumlah 275 sambungan rumah, sementara 
jumlah sambungan rumah di Dusun Jitar dan Dusun Pingitan ada sekitar 500, sehingga SPAMDes ini mampu melayani sekitar 55 persen sambungan rumah di Dusun Jitar dan Dusun Pingitan. Mayoritas pelanggan bekerja sebagai pegawai swasta, PNS, wiraswasta dan petani. Jumlah pelanggan tersebut meningkat dari tahun ke tahun, dari yang awalnya hanya sebanyak 111 sambungan rumah pada tahun 2011 hingga menjadi 275 sambungan rumah saat ini.

Perangkat produksi yang sudah ada di SPAMDes Penggung Air Bersih Tirta Manunggal antara lain: (1) bangunan pengolahan; (2) perangkat operasional; (3) alat pengukur dan pemantauan; dan (4) bangunan penampungan hasil produksi. Proses produksi air di Perpamdes ini dapat dilihat pada Gambar 4 berikut. Mula-mula air dipompa dari dua sumur utama, lalu ditampung di bak penampungan. Selanjutnya air dialirkan dengan pipa dari bak penampungan rumahrumah pelanggan. Sebenarnya masih ada satu sumur lagi, tetapi tidak dimanfaatkan karena airnya berwarna kuning. Sejauh ini, pompa sudah diganti empat kali. Setiap enam bulan sekali dilakukan pembersihan kerak di pompa dan tiga bulan sekali di bak penampungan. Belum ada bentuk inovasi dan pemanfaatan teknologi baru yang digunakan oleh SPAMDes ini. Di masa mendatang, akan dilakukan perluasan jaringan distribusi, tetapi masih terkendala bak penampungan yang kurang tinggi posisinya.

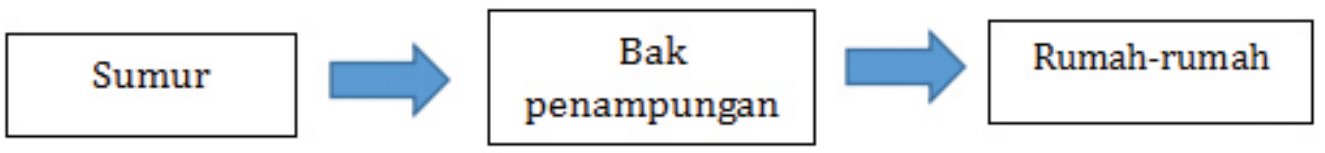

Gambar 4. Proses Produksi Air di SPAMDes Penggung Air Bersih Tirta Manunggal

Pengurus SPAMDes Penggung Air Bersih Tirta Manunggal terpisah dari RW/Dusun dan belum banyakmelibatkan peran Karang Taruna, hanya sebatas melakukan kerjasama intensif dengan Ketua Paguyuban PERPAMDES saja. SPAMDes ini sudah memiliki AD/ART. Setiap bulan, pengurus SPAMDes ini melakukan rapat rutin dan setiap tahun ada Rapat Anggota Tahunan. Dalam rapat anggota tahunan tersebut dibahas evaluasi dan penetapan harga. Setiap pelanggan dikenakan abonemen sebesar Rp5.000,00 perbulan. Selanjutnya, per $\mathrm{m}^{3}$ dikenakan biaya sebesar Rp2.000,00. Penetapan harga tersebut didasarkan pada pertimbangan kenaikan Tarif Dasar Listrik (TDL) dan belanja barang dan peralatan. Besarnya pemakaian pelanggan dapat diukur dengan water meter, sehingga pemakaiannya bisa senantiasa dipantau. Rata-rata pemakaian sambungan rumah per bulan adalah sebesar $15 \mathrm{~m}^{3}$. Masyarakat memanfaatkan air yang dikelola SPAMDes Penggung Air Bersih Tirta Manunggal untuk kebutuhan sehari-hari dan usaha (misalnya kolam ikan dan laundry). SPAMDes ini juga aktif terlibat dalam beberapa kegiatan sosial, seperti memberikan bantuan air cuma-cuma kepada makam saat ada yang meninggal.

\section{SPAMDes Banyu Sejati}

SPAMDes Banyu Sejati berlokasi di Dusun Sejati Pasar, Desa Sumberarum, Kecamatan Moyudan dan sudah berdiri sejak tahun 2008. Air yang dikelola SPAMDes ini bersumber dari sumur yang terletak di Sultan Ground, tepi Sungai Progo. Pasokan air selama ini kurang lancar karena jarak dari sumur ke bak penampungan dan rumah pelanggan cukup jauh $(1,5 \mathrm{~km})$. Kualitas air yang dialirkan juga cukup baik serta sudah dilakukan uji laboratorium sebanyak 2 kali di Dinas Kesehatan Kabupaten Sleman dan dinyatakan layak. Sejauh ini, SPAMDes Penggung Air Bersih Tirta Manunggal baru melakukan kerjasama intensif dengan Ketua Paguyuban PERPAMDES dan Balai Besar Sungai SerayuOpak saja, belum ada kerjasama dengan BUMDes setempat.

Perangkat produksi yang sudah ada di SPAMDes Banyu Sejati antara lain: (1) bangunan pengolahan; (2) perangkat operasional; (3) alat pengukuran dan pemantauan; (4) bangunan 
penampungan air produksi. Mula-mula air dipompa dari sumur utama, lalu ditampung di bak penampungan utama. Selanjutnya air dialirkan dengan pipa dari bak penampungan utama ke bak penampungan kecil. Kemudian, dari bak penampungan kecil tersebut air dialirkan ke rumah-rumah pelanggan dengan menggunakan pipa yang lebih kecil. Akan tetapi, saat ini kondisi pompa sudah rusak maka aktivitas SPAMDes ini sempat berhenti. Di masa mendatang, SPAMDes ini berharap dapat melakukan revitalisasi dan reaktivasi operasionalnya dan sampai sekarang belum dilakukan karena terkendala modal dan faktor masyarakat pelanggannya yang berpendapatan rendah. Dulu pernah dilakukan penggalian (memperdalam) sumur dengan bekerjasama dengan anak-anak KKN UGM karena pompa yang ada sudah rusak maka sumber air tidak dapat dimanfaatkan.

Jumlah pelanggan SPAMDes Banyu Sejati sejauh ini berjumlah 80 kepala keluarga, sementara jumlah kepala keluarga di Dusun Sejati Pasar ada sekitar 110, sehingga SPAMDes ini mampu melayani sekitar 72,73 persen kepala keluarga di Dusun Sejati Pasar. Mayoritas pelanggan bekerja sebagai petani. Jumlah pelanggan tersebut meningkat dari tahun ke tahun, dari yang awalnya hanya sebanyak 20 kepala keluarga pada tahun 2008 hingga menjadi 80 kepala keluarga saat ini.

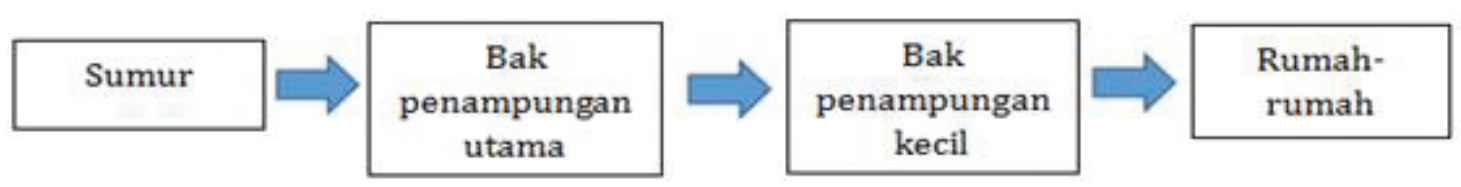

Gambar 5. Proses Produksi Air di SPAMDes Banyu Sejati

Pengurus SPAMDes Banyu Sejati terpisah dari Dusun dan sudah melibatkan beberapa perwakilan RT/RW dan Karang Taruna sebagai pengurus. Penetapan harga didasarkan pada rapat pengurus. Setiap pelanggan dikenakan abonemen sebesar Rp2.000,00 perbulan. Selanjutnya, per $\mathrm{m}^{3}$ dikenakan biaya sebesar Rp1.000,00 Besarnya pemakaian pelanggan dapat diukur dengan water meter, sehingga pemakaiannya dapat senantiasa dipantau. Rata-rata pemakaian sambungan rumah per bulan adalah sebesar 12,5 $\mathrm{m}^{3}$. Masyarakat memanfaatkan air yang dikelola SPAMDes Banyu Sejati untuk kebutuhan sehari-hari saja. Akan tetapi, permasalahan di atas, masyarakat setempat sekarang mengandalkan sumur pribadi. Akan tetapi, selokan di Dusun ini sudah tercemar dengan sampah, maka kualitas air yang dipompa dari sumur pribadi kualitasnya kurang baik. Gambar 6a hingga 8b berikut menunjukkan beberapa foto yang diperoleh penulis selama observasi di lapangan.

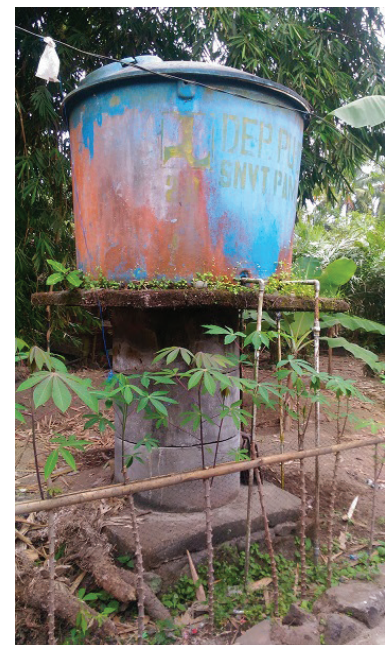

a

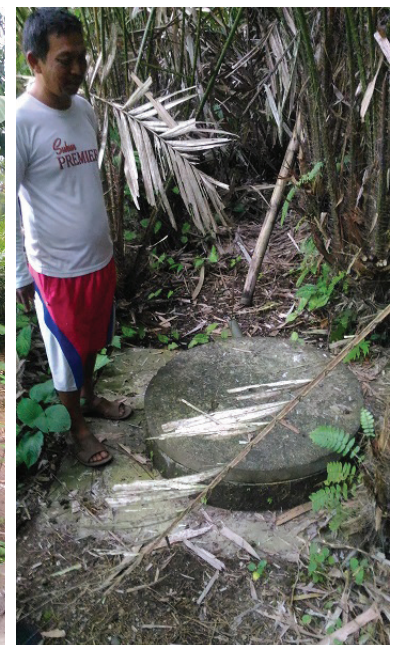

b
Gambar 6.

a. Kondisi Bak Penampungan Air Milik SPAMDes di Dusun Dukuh

b. Kondisi Sumur yang Dikelola oleh SPAMDes di Dusun Dukuh 


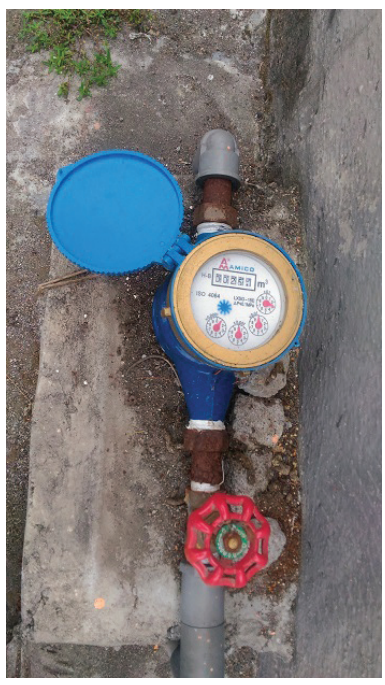

a

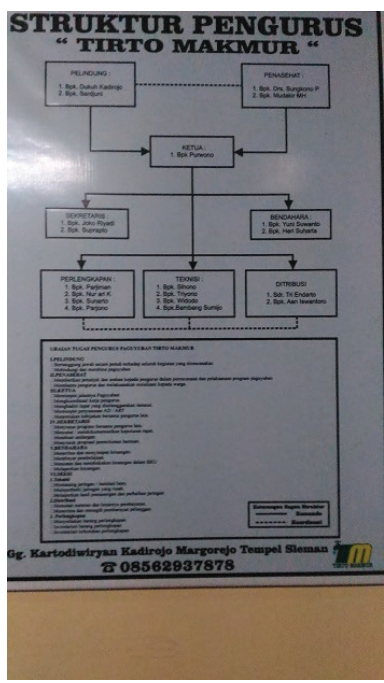

$\mathrm{b}$

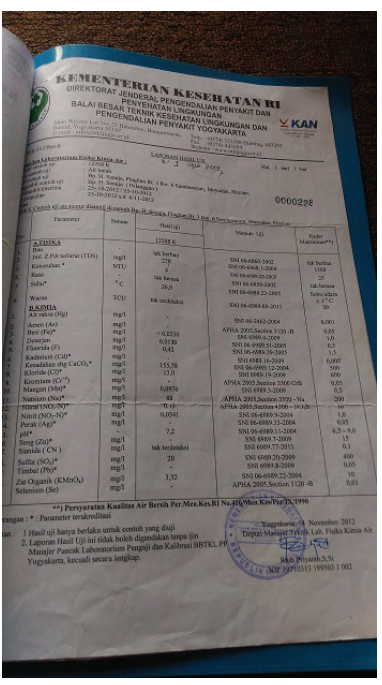

a

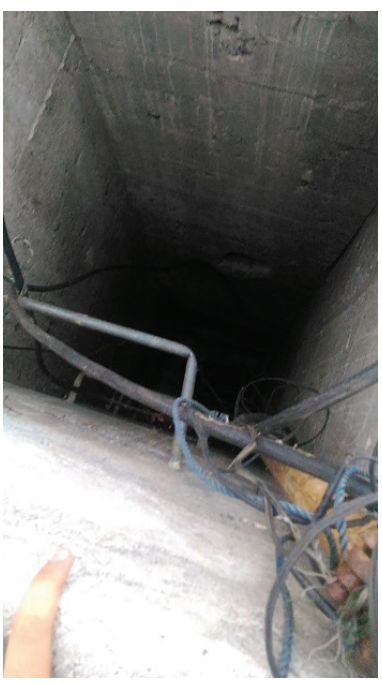

$\mathrm{b}$

Gambar 7.

a. Water Meter Milik Pelanggan SPAMDes Tirto Makmur

\section{b. Struktur Organisasi SPAMDes Tirto Makmur}

\section{Arah Pengembangan SPAMDes}

Tabel 1 berikut merangkum studi kasus empat SPAMDes di atas. Secara umum, SPAMDes yang sudah sukses memiliki karakteristik yang berbeda dengan SPAMDes yang kurang sukses. Perbedaan tersebut adalah faktor kelembagaan, yaitu: (1) Pengurus

Gambar 8.

a. Contoh Berkas Hasil Uji Laboratorium Milik SPAMDes Penggung Air Bersih Tirta Manunggal

b. Kondisi Sumur yang Digunakan SPAMDes Banyu Sejati yang Pompanya Sudah Rusak dan Sumber Airnya Mengering

terpisah dari RW atau dusun; dan (2) Sudah memiliki AD/ART. Sementara itu, SPAMDes yang kurang sukses mengalami kesulitan dalam menjaga kelancaran pasokan air, baik karena faktor musiman maupun kekurangan modal untuk mengganti pompa yang sudah rusak.

Tabel 1.

Rangkuman Studi Kasus SPAMDes

\begin{tabular}{|c|c|c|}
\hline & Sukses & Kurang Sukses \\
\hline \multirow[t]{2}{*}{ Gravitasi } & Tirta Makmur & Dusun Dukuh \\
\hline & $\begin{array}{l}\text { 1. Sumber air dari sumur yang terletak di tanah } \\
\text { kas desa } \\
\text { 2. Pernah melakukan uji lab (2015) dan } \\
\text { dinyatakan layak } \\
\text { 3. Belum ada kerjasama dengan BUMDes } \\
\text { setempat } \\
\text { 4. Pasokan air lancar dan sudah menggunakan } \\
\text { kaporit } \\
\text { 5. Kekurangan modal untuk perluasan jaringan } \\
\text { (pompa dan pipa) } \\
\text { 6. Pengurus terpisah dari perangkat RW atau } \\
\text { dusun dan sudah melibatkan Karang Taruna } \\
\text { 7. Harga: abonemen Rp } 3000 \text { per bulan dan } \\
\text { selanjutnya Rp } 500 \text { per m3 } \\
\text { 8. Sudah ada AD/ART } \\
\text { 9. Jumlah pelanggan cenderung stagnan dan } \\
\text { cakupan layanan mencapai } 47,86 \%\end{array}$ & $\begin{array}{l}\text { 1. Sumber air dari sumur yang terletak di } \\
\text { tanah kas desa dan ada yang terletak di } \\
\text { tanah penduduk } \\
\text { 2. Baru sebatas kelompok gotong royong } \\
\text { 3. Belum banyak melibatkan peran Karang } \\
\text { Taruna } \\
\text { 4. Pasokan air kurang lancar karena } \\
\text { tergantung musim } \\
\text { 5. Pengurus terintegrasi dengan RT atau } \\
\text { dusun } \\
\text { 6. Harga: Rp } 5000 \text { per bulan berapapun } \\
\text { pemakaian airnya } \\
\text { 7. Jumlah pelanggan cenderung turun dan } \\
\text { cakupan layanan mencapai } 27,69 \%\end{array}$ \\
\hline
\end{tabular}




\begin{tabular}{|c|c|c|}
\hline & Sukses & Kurang Sukses \\
\hline & Tirta Manunggal & Banyu Sejati \\
\hline Pompa & $\begin{array}{l}\text { 1. Sumber air dari sumur yang terletak di tanah } \\
\text { negara (Kementerian PU) } \\
\text { 2. Pernah melakukan uji lab (2012) dua kali dan } \\
\text { dinyatakan layak } \\
\text { 3. Belum ada kerjasama dengan BUMDes } \\
\text { setempat } \\
\text { 4. Pasokan air lancar } \\
\text { 5. Ada rencana perluasan jaringan tetapi } \\
\text { terkendala bak penampungan yang kurang } \\
\text { tinggi posisinya } \\
\text { 6. Pengurus terpisah dari perangkat RW atau } \\
\text { dusun } \\
\text { 7. Harga: abonemen Rp } 5000 \text { per bulan dan } \\
\text { selanjutnya Rp } 2000 \text { per m3 } \\
\text { 8. Sudah ada AD/ART } \\
\text { 9. Jumlah pelanggan cenderung naik dan } \\
\text { cakupan layanan mencapai } 55 \%\end{array}$ & $\begin{array}{l}\text { 1. Sumber air dari sumur yang terletak di } \\
\text { Sultan Ground } \\
\text { 2. Pernah melakukan uji lab } 2 \text { kali dan } \\
\text { dinyatakan layak } \\
\text { 3. Belum ada kerjasama dengan BUMDes } \\
\text { setempat } \\
\text { 4. Pasokan air kurang lancar karena jarak } \\
\text { sumur ke bak penampungan jauh }(1,5 \mathrm{~km}) \\
\text { 5. Ada rencana revitalisasi dan reaktivasi } \\
\text { operasionalnya, karena pompa sudah rusak } \\
\text { 6. Pengurus terpisah dari Dusun, tetapi ada } \\
\text { perwakilan RT dan Karang Taruna } \\
\text { 7. Harga: abonemen Rp } 2000 \text { per bulan dan } \\
\text { selanjutnya Rp } 1000 \text { per m3 } \\
\text { 8. Jumlah pelanggan cenderung naik dan } \\
\text { cakupan layanan mencapai 72,73\% }\end{array}$ \\
\hline
\end{tabular}

Sumber: Observasi Lapangan (2017).

Kebanyakan penyedia air minum di pedesaan, permasalahan yang paling sering dihadapi adalah ketika tahap operasi dan perawatan (Veerashekharappa, 1999). Hal ini paling terlihat pada SPAMDes Banyu Sejati, di mana pengurus SPAMDes kesulitan untuk membeli pompa pengganti. Rendahnya tarif yang dikenakan kepada pelanggan menjadi penyebabnya. Oleh karena itu, untuk menjaga kesehatan keuangan di SPAMDes ini maupun SPAMDes lainnya, diperlukan pengaturan tarif yang jelas. Pelanggan SPAMDes yang memiliki usaha seperti kolam pemancingan, laundry ataupun cuci mobil bisa dikenakan tarif yang progresif seperti pada PDAM (Rietveld et al., 2000). Misalnya, setiap tambahan pemakaian $5 \mathrm{~m}^{3}$ dikenakan kenaikan tarif per $\mathrm{m}^{3}$ sebesar $\mathrm{Rp}$ 2.500. Tarif yang progresif ini digunakan untuk menutup biaya operasi dan perawatan agar mampu memberikan layanan yang lebih baik kepada semua pelanggan. Atau, bisa juga pengguna yang memiliki usaha kolam pemancingan, laundry ataupun cuci mobil tidak dibolehkan sekalian menjadi pelanggan SPAMDes, mengingat fungsi utama SPAMDes adalah menyediakan air minum yang layak untuk kebutuhan hidup sehari-hari saja bagi penggunanya.

Menariknya, dari keempat SPAMDes yang diobservasi tidak ada satupun yang sudah melakukan kerjasama dengan BUMDes. Padahal, jika sudah bekerjasama dengan
BUMDes, tentu bantuan untuk pelatihan ataupun peralatan untuk perluasan jaringan bisa masuk dengan mudah. Akan tetapi,yang menjadi pertimbangan pengurus keempat SPAMDes tersebut adalah aset yang mereka kelola nanti harus dibagi dengan Pemerintah Desa. Oleh karena itu, sebelum bekerjasama atau dibentuk BUMDes perlu diadakan musyawarah pengurus terlebih dahulu untuk membahas kepemilikan aset dan kepengurusan BUMDes mengingat koordinasi dan partisipasi masyarakat adalah faktor kunci keberhasilan program penyediaan air minum di pedesaan (Pant, 1996).

Sejauh ini, pembinaan dan pengembangan SPAMDes dilakukan oleh Dinas Pekerjaan Umum Kabupaten Sleman. Upaya pembinaan dan pengembangan harus senantiasa dilakukan dan bahkan kalau dapat ditingkatkan agar SPAMDes di Kabupaten Sleman mampu memberikan layanan yang optimal. Sejauh ini, partisipasi swasta hanya dalam bentuk pelatihan dari dana Corporate Social Responsibility (CSR) saja. Jika sudah bekerjasama atau dibentuk BUMDes, tentu bantuan dari Pemerintah dan swasta akan lebih mudah masuk, mengingat status badan hukumnya jelas.

\section{SIMPULAN}

Studi ini berhasil mengidentifikasi bahwa beberapa SPAMDes masih belum siap untuk diintegrasikan dengan SPAM Regional 
Kartamantul. Beberapa SPAMDes yang kurang sukses seperti di Dusun Dukuh dan Banyu Sejati masih membutuhkan perbaikan dalam menjaga kelancaran pasokan air dan kelembagaan mereka. Ke depan, SPAMDes yang sudah siap sebaiknya diarahkan untuk bekerjasama dengan atau dibentuk menjadi BUMDes. Dengan bekerjasama atau dibentuk BUMDes, tentu bantuan dari Pemerintah dan swasta akan lebih mudah masuk. Selain itu, dibutuhkan pengaturan tarif yang jelas bagi pengusaha kolam pemancingan, laundry dan cuci mobil, apakah dikenakan tarif yang progresif atau tidak dibolehkan sekalian menjadi pelanggan SPAMDes mengingat fungsi utama SPAMDes adalah menyediakan air minum yang layak untuk kebutuhan hidup sehari-hari saja bagi penggunanya.

Akan tetapi, studi ini masih ada unsur subjektif dari Ketua Paguyuban PERPAMDES. SPAMDes yang sukses dan kurang sukses murni ditentukan oleh Ketua Paguyuban PERPAMDES berdasarkan pengalaman di lapangan. Sejauh ini, belum ada indikator baku yang dapat digunakan untuk membedakan SPAMDes yang sukses dan kurang sukses. Oleh karena itu, peneliti menyarankan agar pada studi berikutnya terkait penilaian kesiapan SPAM Regional Kartamantul perlu diidentifikasi indikator baku agar unsur subjektif bisa dikurangi.

\section{DAFTAR PUSTAKA}

Cullet, P. 2009. “New Policy Framework for Rural Drinking Water Supply:
Swajaldhara Guidelines", Economic and Political Weekly, Vol. 44: 47-54.

Heikoop, R. 2001. “Towards Enhancing Access to Affordable Water Supply for the Urban Poor: Six Communities in Cebu City", Phillipine Quarterly of Culture and Society, Vol. 29: 252-266.

Matzger, H., and M. Moench. 1994. “Ground Water Availability for Drinking in Gujarat: Quantity, Quality and Health Dimensions", Economic and Political Weekly, Vol. 29: A31-A41.

Notosugondo, H. 1975. “Water Supply Problems and Developments in Indonesia", American Water Works Association, Vol. 67: 298-300.

Pant, S. K. 1996. “How Relevant Are Rural Water Supply Programmes?", Economic and Political Weekly, Vol. 31: 3163-3164.

Rietveld, P., J. Rouwendal, and B. Zwart. 2000. "Block Rate Pricing of Water in Indonesia: An Analysis of Welfare Effects", Bulletin of Indonesian Economic Studies, Vol. 36: 73-92.

Saha, P. K. 1971. "Self-Financing Urban Water Supply: A Model for Asansol Durgapur", Economic and Political Weekly, Vol. 6: 1285-1290.

Veerashekharappa. 1999. "Reforms in Drinking Water Supply: Perspective and Problems", Economic and Political Weekly, Vol. 34: 3695-3696. 